\title{
ANALISIS SARANA PRAKTIK PADA MATA PELAJARAN PEMELIHARAAN KELISTRIKAN KENDARAAN RINGAN DI SMK
}

 \\ Universitas Pendidikan Indonesia \\ Jl. Dr. Setiabudhi No. 229 Bandung 40154 \\ yansaputra0@gmail.com
}

\begin{abstract}
ABSTRAK
Penelitian ini bertujuan untuk mengetahui ketersediaan sarana praktik dan rasio alat dengan jumlah siswa pada mata pelajaran pemeliharaan kelistrikan kendaraan ringan di SMK Pekerjaan Umum Negeri Bandung. Metode yang digunakan dalam penelitian ini adalah metode deskriptif dengan instrumen observasi, wawancara dan dokumentasi. Hasil penelitian menunjukkan bahwa tingkat ketersediaan sarana praktik sebesar $90 \%$ dan rasio jumlah alat dengan jumlah siswa sebesar $83 \%$, sehingga ketersediaan sarana praktik dan rasio alat dengan jumlah siswa dikategorikan sangat layak, hal tersebut menunjukkan faktor yang mempengaruhi hasil belajar siswa belum mencapai KKM bukan terletak pada faktor sarana pembelajaran, ada faktor lainya seperti kurikulum, metode mengajar yang diterapkan guru, kesiapan siswa, waktu sekolah dan lingkungan sosial siswa di sekolah.
\end{abstract}

Kata kunci: sarana praktik, kelistrikan, kendaraan ringan

\section{PENDAHULUAN}

Pendidikan yang diharapkan untuk menghasilkan SDM yang berkompeten dan berdaya saing yaitu Sekolah Menengah Kejuruan (SMK). SMK merupakan salah satu jenjang pendidikan formal yang dikhususkan dalam mencetak lulusan yang berkompeten dalam bidangnya. Sekolah Menengah Kejuruan merupakan lembaga pendidikan untuk menciptakan SDM yang memiliki keterampilan sesuai dengan bidang keahlian tertentu (Purwanto dan Sukardi, 2015). Menciptakan SDM yang berkompeten dalam bidangnya SMK harus memenuhi 8 (delapan) Standar Nasional Pendidikan (SNP) diantaranya standar sarana dan prasarana.

Standar sarana dan prasarana memiliki peran yang besar didalam keberhasilan siswa dalam memperoleh informasi disekolah, bahkan apabila sarana dan prasarana disekolah tidak terpenuhi dengan baik dapat mengakibatkan proses pembelajaran terkendala. peralatan dan perlengkapan yang disediakan di sekolah mempunyai pengaruh besar terhadap program mengajar-belajar. Persediaan yang kurang dan tidak memadai akan menghambat proses belajar mengajar (Daryanto, 2008). Proses Belajar Mengajar (PBM) atau Kegiatan Belajar Mengajar (KBM) akan semakin sukses bila ditunjang dengan sarana dan prasarana pendidikan yang memadai (Gunawan, 2002). Sarana dan prasarana sekolah dapat dijabarkan sebagai fasilitas untuk menunjang PBM bagi siswa, seperti gedung

\footnotetext{
${ }^{1}$ Mahasiswa Departemen Pendidikan Teknik Mesin FPTK, UPI

${ }^{2}$ Dosen Departemen Pendidikan Teknik Mesin FPTK, UPI

${ }^{3}$ Dosen Departemen Pendidikan Teknik Mesin FPTK, UPI
} 
sekolah yang terdiri dari ruangan kelas, perpustakaan, laboratorium, bengkel kerja/workshop, dan lain-lain.

Workshop merupakan fasilitas untuk menunjang PBM praktik bagi siswa. Lancarnya kegiatan praktik tersebut, ditunjang dengan fasilitas workshop yang memadai seperti gedung, peralatan, bahan dan perlengkapan lainya. Tanpa adanya fasilitas tersebut kegiatan praktik tidak akan terlaksana dan tujuan pembelajaran tidak tercapai.

Faktor sekolah yang mempengaruhi belajar mencakup metode mengajar, kurikulum, relasi guru dengan siswa, relasi siswa dengan siswa, disiplin sekolah, alat pelajaran, waktu sekolah, standar pelajaran, keadaan gedung, metode belajar dan tugas rumah (Slameto, 2010). Faktor ekstern yang berpengaruh pada aktivitas belajar mencakup guru sebagai pembina siswa belajar, prasarana dan sarana pembelajaran, kebijakan penilaian, lingkungan sosial siswa disekolah dan kurikulum sekolah (Dimyati \& Mudjiono, 2013).

Sarana pembelajaran erat hubunganya dengan hasil belajar siswa, karena sarana pembelajaran yang dipakai oleh guru pada waktu mengajar dipakai pula oleh siswa untuk menerima bahan yang diajarkan, oleh karena itu semakin lengkapnya sarana pembelajaran maka proses pembelajaran menjadi semakin lancar dan siswa mudah menerima pelajaran. Semakin siswa mudah menerima pelajaran akan berdampak terhadap hasil belajar siswa. Alat pembelajaran yang lengkap dan tepat akan mempelancar penerimaan bahan pelajaran yang diberikan kepada siswa. Jika siswa mudah menerima pelajaran dan menguasainya, maka belajarnya akan menjadi lebih giat dan maju.

Sarana pendidikan, yaitu perlengkapan yang secara langsung dipergunakan untuk proses pendidikan, seperti meja, kursi, kelas, dan media pengajaran (Maniarti, 2011). Sarana pendidikan, alat langsung untuk mencapai tujuan pendidikan. Misalnya: ruang, buku, perpustakaan, laboratorium dan sebagainya.

\section{METODE PENELITIAN}

Metode yang digunakan dalam penelitian ini yaitu metode deskriptif dengan pendekatan kuantitatif. Tempat pelaksanaan penelitian ini mengambil lokasi di workshop teknik kendaraan ringan SMK Pekerjaan Umum Negeri Bandung. Populasi dan sampel dalam penelitian ini adalah seluruh sarana praktik yang digunakan dalam pelajaran pemeliharaan kelistrikan kendaraan ringan di SMK Pekerjaan Umum Negeri Bandung.

Analisis data yang digunakan dalam penelitian ini yaitu dengan statistik deskriptif. Statistik deskriptif digunakan untuk memperoleh gambaran data hasil penelitian sebagai pemecahan masalah penelitian dari data mentah yang dikumpulkan dengan menggunakan 
alat pengumpul data. Data-data yang dikumpulkan pada penelitian ini berasal dari hasil observasi, wawancara dan dokumentasi.

\section{HASIL PENELITIAN}

Hasil observasi penelitian mengenai ketersedian sarana praktik pemeliharaan kelistrikan kendaraan ringan yang tersedia yang meliputi perabot, peralatan untuk pekerjaan kelistrikan otomotif, media pendidikan, perlengkapan lain dan alat pelindung diri, dari total 71 item sarana praktik yang diteliti diperoleh 64 item sarana praktik tersedia, dan 7 item sarana praktik belum tersedia.

Rasio jumlah alat praktik pemeliharaan kelistrikan kendaraan ringan dengan jumlah siswa yang meliputi perabot, peralatan untuk pekerjaan kelistrikan otomotif, media pendidikan, perlengkapan lain dan alat pelindung diri, dari total 66 item sarana praktik yang diteliti diperoleh 55 item rasio alat telah sesuai, dan 11 item rasio alat belum sesuai.

\section{PEMBAHASAN}

Ketersediaan sarana praktik pada mata pelajaran pemeliharan kelistrikan kendaraan ringan yang meliputi perabot (meja kerja, kursi kerja, lemari simpan alat dan bahan), peralatan untuk pekerjaan kelistrikan otomotif (sistem stater, pengapian dan pengisian), media pendidikan (papan tulis), perlengkapan lain (kotak kontak, tempat sampah) dan alat pelindung diri (APD) mencapai 90\%. Artinya secara kuantitas tingkat pencapaian ketersediaan sarana praktik dikategorikan sangat layak dan sudah sesuai dengan standar yang ditetapkan.

Rasio jumlah alat praktik yang tersedia dengan jumlah siswa pada mata pelajaran pemeliharaan kelistrikan kendaraan ringan yang meliputi perabot (meja kerja, kursi kerja, lemari simpan alat dan bahan), peralatan untuk pekerjaan kelistrikan otomotif (sistem stater, pengapian dan pengisian), media pendidikan (papan tulis) dan perlengkapan lain (kotak kontak, tempat sampah) mencapai 83\%. Artinya secara kuantitas tingkat pencapaian rasio jumlah alat praktik yang tersedia dengan jumlah siswa dikategorikan sangat layak dan telah sesuai dengan standar yang ditetapkan.

Faktor yang mempengaruhi hasil belajar siswa sangat banyak, diantaranya adalah ketersediaan alat/sarana dalam proses pembelajaran. Alat/sarana pembelajaran yang lengkap dan tepat akan mempelancar penerimaan bahan pelajaran yang diberikan kepada siswa, yang memungkinkan siswa bisa mencapai hasil belajar yang lebih baik. Lebih lanjut, faktor yang mempengaruhi hasil belajar siswa yaitu mencakup guru sebagai 
pembina siswa belajar, prasarana dan sarana pembelajaran, kebijakan penilaian, lingkungan sosial siswa disekolah dan kurikulum sekolah. Jika sarana yang digunakan dalam proses pembelajaran sudah cukup memadai, tetapi hasil belajar siswa belum sesuai harapan. Ada faktor lain yang mempengaruhi hasil belajar siswa tersebut.

Diketahui bahwa faktor yang mempengaruhi hasil belajar siswa pada mata pelajaran pemeliharaan kelistrikan kendaraan ringan bukan terletak pada faktor sarana praktik. Ada faktor lainnya yang mempengaruhi hasil belajar siswa tersebut. Faktor-faktor yang mempengaruhi hasil belajar yaitu metode mengajar, kurikulum, relasi guru dengan siswa, relasi siswa dengan siswa, disiplin sekolah, alat pelajaran, waktu sekolah, standar pelajaran, keadaan gedung, metode belajar dan tugas rumah (Maniarti, 2011).

\section{KESIMPULAN}

Kesimpulan penelitian ini yaitu ketersediaan sarana praktik dan rRasio jumlah alat praktik yang tersedia dengan jumlah siswa pada mata pelajaran pemeliharaan kelistrikan kendaraan ringan di SMK Pekerjaan Umum Negeri Bandung dikategorikan sangat layak dan sudah memenuhi standar. Namun, faktor sarana praktik pada mata pelajaran pemeliharaan kelistrikan kendaraan ringan belum dapat meningkatkan hasil belajar siswa.

\section{REFERENSI}

Daryanto, H. M. (2008). Administrasi Pendidikan. Jakarta: Rineka Cipta.

Dimyati dan Mudjiono. (2013). Belajar dan Pembelajaran. Jakarta: Rineka Cipta.

Gunawan, A. (2002). Administrasi Sekolah. Jakarta: Rineka Cipta.

Maniarti, S. (2011). Administrasi dan Manajemen Sekolah. Jogjakarta: Ar Ruzz Media.

Purwanto dan Sukardi, T. (2015). Pengelolaan Bengkel Praktik SMK Teknik Pemesinan di Kabupaten Purworejo. Jurnal Pendidikan Teknologi dan Kejuruan, 22 (3). hlm.291306.

Slameto. (2010). Belajar dan Faktor-faktor yang Mempengaruhi. Jakarta: Rineka Cipta. 